\title{
Med åpent blikk utenfor egen institusjon
}

\author{
Geir Hoff \\ Adresse: Vestfoldbanen (Kreftregisteret-Telemark Sentralsjukehus) \\ E-post: hofg@online.no
}

ENGLISH SUMMARY

Hoff G. With an open view outside one's own institution. Nor J Epidemiol 2001; 11 (2): 133-135.

Even in a country like Norway, with a poor reputation for investment in medical research, some studies may materialise against all odds. This is the story about the difficult start and first few years of flexible sigmoidoscopy screening studies in Norway. It started in the peripheral county of Telemark with the Telemark Polyp Study no. I (TPS-I) in 1983. We now see the success of the Norwegian Colorectal Cancer Prevention (NORCCAP) study, which is an on-going large-scale version of the TPS-I study comprising 21,000 men and women to be offered flexible sigmoidoscopy screening in Oslo and Telemark after randomised invitation from the population registry.

Noen prosjekter blir til mot alle odds. Jeg er bedt om å fortelle en slik historie. Det dreier seg om "Telemark Polyp Study no. I" (TPS-I) og fortsettelsen "Forebyggende undersøkelser mot tarmkreft", NORCCAPprosjektet, som nå er godt forankret i Kreftregisteret. Festskriv gir en sjelden anledning til frihet fra vitenskapelig dokumentasjon, men desto større krav til perspektiv, ytringer, oppstemt milepelsretorikk og oppmuntringer. Denne historien håper jeg kan gi noe til noen, men den er neppe like festlig for alle.

Historien startet i begynnelsen av 1980-årene med at en tilfreds, underordnet kliniker (undertegnede) måtte innse at han, som rendyrket kliniker, ville komme sist $\mathrm{i}$ køen til de fete jobbene, uansett hvor godt han jobbet. (Underlig hvilke forestillinger man kan ha om hva som er "fete" jobber.) Tanken på kveldstids"forskning" i form av kasuistiske meddelelser og retrospektivt oppgjorte materialer fra et perifert sentralsykehus ga ikke akkurat oppstemthet. Erkjennelsen om at enhver leges rykte som "glitrende kliniker", "pasientenes advokat" eller "utrolig arbeidsjern" er sørgelig flyktig og glemt ved arbeidsstedet etter 14 dager, påkalte visse eksistensielle, forebyggende grep for å hindre dyp depresjon eller vedvarende livsløgn om lokal uerstattelighet (meget utbredt avart av "hjelpersyndromet").

En konsensusuttalelse fra internasjonale guruer om at "flexible sigmoidoscopy in population screening is unfeasible" virket meget provoserende på en respektløs assistentlege. Hovedargumentet var at det nærmest var latterlig å tro at folk ville møte til undersøkelse, men det var ingen dokumentasjon eller henvisning til noe "fiasko-forsøk". Her fantes åpenbart en passe ufyselig nisje som ingen ville misunne meg. Med god støtte av noen enkeltpersoner lokalt og etter hvert sentralt, begynte planleggingen.
Det er mye å si om hvordan man bør gå fram på personnivå for å etablere forskning hvor det ikke er noen forskning og hvor alt fokus er på "utkastelse av korridorpasienter" og "kostnadskutt for enhver pris". Kort fortalt, så har jeg tro på allianser i og utenfor det lokale miljø, prøve å la andre (med innflytelse) få følelsen av selv å ha kommet på den spirende idéen du så snedig har sådd, og unngå klare "nei” til dine spørsmål om å få lov til noe. Kom heller tilbake til saken på en litt annen måte $f ø r$ det låser seg, på et annet tidspunkt, kanskje fra en annen person, før du forventer at "neiet" kommer. Det betyr at du må reklamere for "saken" og glemme dine egne markeringsbehov, om du skulle ha noen.

Vi brukte 1 1/2 år på å planlegge TPS-I. Datainnsamlingen i screeningfasen ble gjort unna på 9 uker. Frammøtet ble $81 \%$, dvs. suksess og seier over guruenes pessimisme. Det resultatet kan vi i stor grad takke lokale media for, som forsto betydningen av å unngå sensasjonsoppslag. De gikk for saklighet og samarbeidet hele tiden for å få fram riktig, litt lavmælt informasjon. Prosjektet ble tildelt prisen for beste studie ved Nordisk Gastoenterologisk Kongress i 1983, knapt 3 måneder etter start, dvs. i praksis en pris for studiedesign. Siden er det blitt en rekke priser, bl.a. prisen for beste kliniske studie ved den Europeiske Gastroenterologikongressen (UEGW) i Birmingham i 1997. Til nå foreligger det 20 originalpublikasjoner fra TPSI, to medisinske doktorgrader og én cand.scient.eksamen i klinisk ernæringsfysiologi.

Forut for denne suksessen i forskningens utmark lå det en rekke hindringer, særlig fra sentrale hold. Datatilsynet brukte svaert lang tid på å behandle vår søknad som var formulert som søknad om konsesjon til å opprette et register $o g$, i min uvitenhet, tillatelse til å få bruke Folkeregisteret til uttrekk av gruppene. Datatil- 
synet ga gjentatte beroligende forsikringer over telefonen om at søknaden var meget kurant. Da det kurante svaret omsider forelå, ble jeg gjort oppmerksom på at søknaden om å få bruke Folkeregisteret nok ikke kunne behandles av Datatilsynet, men måtte stiles til Statistisk Sentralbyrå. Den uopplyste amatørforskeren fra forskningens grisgrendte strøk så for seg TPS-I's sammenbrudd. En person i Statistisk Sentralbyrå oppfattet desperasjonen og handlet raskt, men kunne ikke utføre den nødvendige randomiseringen i tide. Vi lå allerede en måned etter tidsskjemaet og hadde ingen mulighet til å styre unna påskeferie og serien med utallige ovalhelger og inneklemte Gro-dager i mai før sommerferien til slutt ville lamme ethvert oppmøte til screening. Valget sto mellom å sette igang umiddelbart $i$ et halsbrekkende tempo med skopier (fleksibel sigmoidoskopi) fra kl. 08 til 22 hver dag i 9 uker med til sammen 2 timers spisepauser hver dag eller å utsette det hele til høsten. Jeg har en strålende kone og meget viljesterke barn, dengang to på 6 og 7 år. Som sagt, en strålende kone. Vi valgte å stå på, nærmest i forbannet trass mot byråkratisk passivitet, i verste fall uten lønn. Den siste helgen før utsending av invitasjonsbrev til deltakerne i TPS-I ble randomiseringen utført på stuegulvet med et utvalg terninger, 400 konvolutter ble påskrevet for hånd, påklistret frimerker og postlagt mandag morgen. Pressekonferanse tirsdag morgen, samme dag som invitasjonene lå i postkassen, en uke før 08-22-jobbingen begynte. Budsjettet dekket ikke assistent i screeningfasen. Dermed var jeg alene om alle skopiene, klystérsetting på alle frammøtte, all registrering og prøvetaking og vask og desinfeksjon av skopene. Skrekkscrenarioet var sykdom hos meg eller mine nærmeste mens dette "one-man-showet" sto på.

I ettertid ble det klart at alternativet, en utsettelse til høsten 1983, ville ha ført til full skrinlegging av prosjektet. Lokalene ble omdisponert og ombygd til annet formål. I tillegg ble HIV allment kjent, og det er tvilsomt om en invasiv tarmundersøkelse ville kunnet bli iverksatt de første årene etter dette. Prosjektet var altså svært nær totalhavari før sjøsettingen. Da hadde det sannsynligvis heller ikke blitt noe av den oppfølgende NORCCAP-studien, som er en kopi av TPS-I, bare i mye større målestokk.

For å få litt balanse i min kritikk av Datatilsynets saksbehandling, må jeg si at min erfaring med Datatilsynet i forhold til NORCCAP, har vært særdeles positiv, både når det gjelder problemforståelse og saksbehandling. Mer på dette temaet med balanse og perspektiv: Selv om Kreftregisteret på en utmerket måte nå står last og brast for og med NORCCAP, så er det litt ironisk i ettertid å se at det var Kreftregisteret som i sin tid rådet Helsedirektoratet til ikke å støtte TPS-I uten gjennomgripende endringer i protokollen. Helsedirektoratet (Statens Helsetilsyn) bekler nå styreledervervet i NORCCAP-prosjektet. Med holdningen om å ikke nødvendigvis ta et "nei" for et "NEI" $i$ 1983, allierte jeg meg med statistiker som støttet mitt syn på at søknaden vår umulig kunne ha vært lest ordentlig. Det er ikke lett å formulere en slik anke og grusom anklage på en tilstrekkelig høflig måte. Det gikk naturligvis ikke. Landsforeningen mot Kreft fulgte opp med blankt avslag. Jeg følte sterkt at jeg ikke behersket skriftlig framstillingsevne. Skriftlige søknader og ankebrev var et sårt tema. Min første samtale noensinne med Lilly Christensen i den "lille" Kreftforeningen på den tid, Norsk Forening til Kreftens Bekjempelse, fulgt opp med skriftlig søknad, reddet driftsmidler til det aller nødvendigste for å komme i gang. Resten regnet jeg faktisk med ville "ordne seg under marsjen". Det jo ofte sånn det fungerer i Norge. Kort tid etter oppstart, før suksessen ble kjent, satset Martin Flatners legat også "risikokapital" på vårt foretak.

Det er naturligvis ikke lett å få sentral støtte til forskning i forskningens utkantstrøk. I 1988-89 prøvde vi oss igjen med en "spin-off" studie på TPS-I. Temaet var forekomst av kolorektale polypper i befolkningsutvalg som soknet til klorerte drikkevannskilder med forskjellig organisk innhold og forskjellig potensiale for å danne kreftfremkallende trihalometaner, med andre ord et tema som burde engasjere ganske mange $i$ den offentlige forvaltning, politikere og helsemyndigheter. Resultatet kunne få store konsekvenser for hvordan vi behandler drikkevann. Vi trengte i alt kr. 50000 til månedlige analyser av drikkevann i løpet av ett år. Vi hadde god tid til å teste ut den offentlige viljen til å øke kunnskapen om et potensielt brennbart tema. Befolkningsgruppene var definert, skopiene var utført og det var ingen umiddelbare planer om nedleggelse av aktuelle vannverk eller endring av desinfeksjonsrutiner. Søknad ble avslått av Helsedirektoratet, SIFF, Statens Næringsmiddeltilsyn og Moderniseringsprogrammet i Telemark Fylkeskommune. Avslagene var mest av typen "interessant, men vi driver ikke med forskning" eller "dessverre, men vi ønsker å bli holdt orientert om resultatene". Nok en gang fikk vi det vi trengte fra en frivillig organisasjon, Den Norske Kreftforening, og vi ble derfor i stand til å orientere om resultatene til de "ressursfattige".

Etter 10 år var TPS-I fortsatt den eneste prospektive, randomiserte studie på sigmoidoskopiscreening $\mathrm{i}$ en normalbefolkning. Materialet var enestående i verden og vi burde mobilisere krefter for å etterundersøke hele screeninggruppen og utføre første gangs undersøkelse også av kontrollgruppen med koloskopi, dvs. befolkningsscreening med full koloskopi. Dette var heller ikke gjort tidligere og ville kreve en rekke egenskaper hos den som skulle utføre undersøkelsen. I rett tid dukket fersk assistentlege Espen Thiis-Evensen opp på medisinsk avdeling, Telemark Sentralsjukehus med alle de egenskapene som krevdes. Men uten forskningsbakgrunn nådde han ikke opp som stipendiatsøker. Det løste vi ved at jeg søkte i mitt navn, fikk midler, og frikjøpte Thiis-Evensen. Han gjennomførte skopiene i 1996, fortsatte innhøstingen av priser ved 
forskjellige kongresser og disputerte på sitt arbeid i mars 2001.

I 1996 jaktet vi på nytt på stipendiatmidler til Thiis-Evensen. Primært for å "vise ansikt" meldte jeg meg på til årets UICC konferanse som ble arrangert $\mathrm{i}$ Oslo av Den Norske Kreftforening. Hanna Hånes, frilance journalist for DNK, hadde sett navnet mitt på deltakerlisten og ringte et par dager før konferansen for å høre hvordan det gikk med TPS-I. Hun fikk oppdaterte resultater. Noen timer senere fikk jeg beskjed om å komme rett til pressekonferanse straks jeg kom til Oslo på kongressens første dag. Alt som skjedde de neste timene var ganske morsomt og helt i tråd med Askeladden, halve kongeriket, den norske folkesjel og at "alt ordner seg under marsjen": Prime time innslag om TPS-I i radio og TV med støtte erklæringer om at DNK vil gjøre kolorektal screening til et hovedsatsningsområde. Jeg rakk ikke å delta ved selve UICC kongressen, vi hadde intet innslag om TPS-I der og kongressdeltakere som hadde sett TV-innslaget om TPS-I fra kongressens pressekonferanse lurte på om det dreide seg om det samme møtet. Thiis-Evensen fikk stipendiatmidlene.

TV-aksjonen "Krafttak mot Kreft" høsten 1997 ble en formidabel suksess. Eget TV-program om TPS-I noen dager i forveien. Resten var også opptur. Norsk Gastrointestinal Cancergruppe hadde tidligere samme år nedsatt en prosjektgruppe til å utforme en protokoll for et screeningprosjekt. DNK stilte seg som økonomisk garantist. Sosial- og Helsedepartementet påtok seg det formelle eierskap og delte det økonomiske ansvar med DNK, og Norsk Kreftplan la opp til endoskopiscreening i 1-2 prøvefylker. Vi brukte et år (1998) på den praktiske planleggingen av NORCCAPprosjektet som er beskrevet som "norgeshistoriens største randomiserte prosjekt som legemiddelindustrien ikke sponser". Britene brukte 2-3 år på planlegging av et tilsvarende prosjekt. Planleggingsåret ga en følelse av bred organisatorisk og økonomisk støtte. Det er mye å si om det ene året vi brukte til planleggingen, blant annet den smertefulle erkjennelsen at vi i Norge ikke bare er fattige på midler som vi vil la tilflyte forskning, men kanskje også fattige på ideer, i hvert fall synliggjorte ideer. En oppfordring til en rekke institutter og alle regions- og sentralsykehus om å benytte prosjektets unike mulighet til å komme fram med hypoteser til mulige delprosjekter ga intet resultat. I selve prosjektet har framdriftsplanen holdt, budsjettet har holdt, funnene er som vi hadde forventet og innsamling av prøvemateriell og datagrunnlag til delprosjektene fungerer. Til alt overmål har det også vanket en europeisk PR-pris for bevisstgjøring og formidling.

Som fryktet, ble det ubehagelig å hente fram fortrengt fortid og sette denne historien på trykk. Jeg har et utmerket samarbeid med personer og institusjoner som tidligere ikke alltid har imponert med åpent blikk for tverrfaglig forskning eller forskning utenfor egen institusjon eller etablert miljø. Vi er et lite land med et svært lite forskningsmiljø. La oss ikke hindre hverandre i å la det ekspandere noe, og la oss i hvert fall ikke slåss mot hverandre fordi om vi skulle være så uheldige å underkjenne verdien av hverandres arbeid eller ideer. Det er forbilledlig å gjøre som Kreftregisteret nå har gjort en periode: $\AA$ knytte til seg klinikere og andre fra andre miljøer i tidsbolker eller delstillinger for gjensidig stimulering og utvidelse av norsk medisinsk forskning. Der ligger det et enormt potensiale. Her tror jeg vi finner ungdomskilden for 50-åringen. Gratulerer med framtiden! 
